\author{
I.O. DUDKA ${ }^{1}$, V.P. HAYOVA ${ }^{1}$, V.G. KORYTNIANSKA ${ }^{2}$ \\ ${ }^{1}$ M.G. Kholodny Institute of Botany, National Academy of Sciences of Ukraine \\ 2 Tereschenkivska Str., Kyiv 01601 Ukraine \\ i.dudka@mail.ru, vera.hayova@i.ua \\ ${ }^{2}$ National Research Restoration Centre of Ukraine \\ 7 Voznesensky, Odessa, 65007 Ukraine \\ kutovaya@rambler.ru
}

\title{
THE FIRST REPORT OF PERONOSPORA VERBENAE, A DOWNY MILDEW ON VERBENA OFFICINALIS, IN UKRAINE
}

K e y w o $r$ d s: Oomycota, Peronosporales, downy mildews, Peronospora, Verbena

\begin{abstract}
A rare downy mildew, Peronospora verbenae on Verbena officinalis, is newly reported from Ukraine. The species recently described from Germany and recorded in the UK and Czech Republic is unknown outside Europe. Using SEM, additional ultrastructural features of the ultimate branchlets and conidiospore surface were discovered. Original illustrations of the revealed morphological characters are provided.
\end{abstract}

In June 2012, several plants of Verbena officinalis L. (Verbenaceae) with typical symptoms of downy mildew on living leaves were observed in the Danube Biosphere Reserve (Odessa Region, Ukraine). The collected specimen was identified as Peronospora verbenae $\mathrm{U}$. Braun, Jage, Udo Richt. et H.J. Zimm. (Peronosporales, Peronosporomycetes, Chromista).

The first specimens of Peronospora on $V$. officinalis were recorded in Germany in 2007-2008 and described as a new species (Braun et al., 2009). In May 2009, the same Peronospora infection was also reported from England (UK) (Anon., 2009). In August and September of the same year, $P$. verbenae was found in the Czech Republic (Choi et al., 2010). The present collection is therefore the forth record of the species in Europe.

So far all previously known specimens of $P$. verbenae have been studied under light microscopy (LM). Since

(C) I.O. DUDKA, V.P. HAYOVA, V.G. KORYTNIANSKA, 2013 scanning electron microscopy (SEM) proved to be a useful tool in taxonomic studies of downy mildews (Thines, 2006), we examined our specimen using both LM and SEM. Some additional micromorphological characters of $P$. verbenae revealed under SEM are depicted below. The specimen is deposited in the Herbarium of the M.G. Kholodny Institute of Botany $(K W)$.

Peronospora verbenae U. Braun, Jage, A.U. Richt. et H.J. Zimm. (Figs. 1-4).

Colonies as more or less dense tufts, hypophyllous, scattered, rarely confluent, usually on yellowish spots visible also on the upper leaf surface. Down whitish, dirty white to greyish. Conidiosporophores solitary, protruding through stomata, sometimes with inflated and/or truncate base, dendroid, 200-400(-450) $\mu \mathrm{m}$ long; trunk erect, $100-240 \times 7-10 \mu \mathrm{m}$, subhyaline, smooth, monopodially branched, callose plugs absent; branches straight to slightly curved, in up to $5-6(-7)$ orders; ultimate branchlets almost straight to curved, the longer ones $12-20 \mu \mathrm{m}$ long, the shorter ones $4-12 \mu \mathrm{m}$ long, $2-4 \mu \mathrm{m}$ wide at the base, occasionally slightly widening before ramification, tips obtuse, subtruncate, subacute or tubular. Conidiospores narrowly to broadly ellipsoidal, $(20-) 25-35(-39) \times 15-20(-24) \mu \mathrm{m}$, length/width ratio 1.2-2.0, grey, greyish-violaceous 

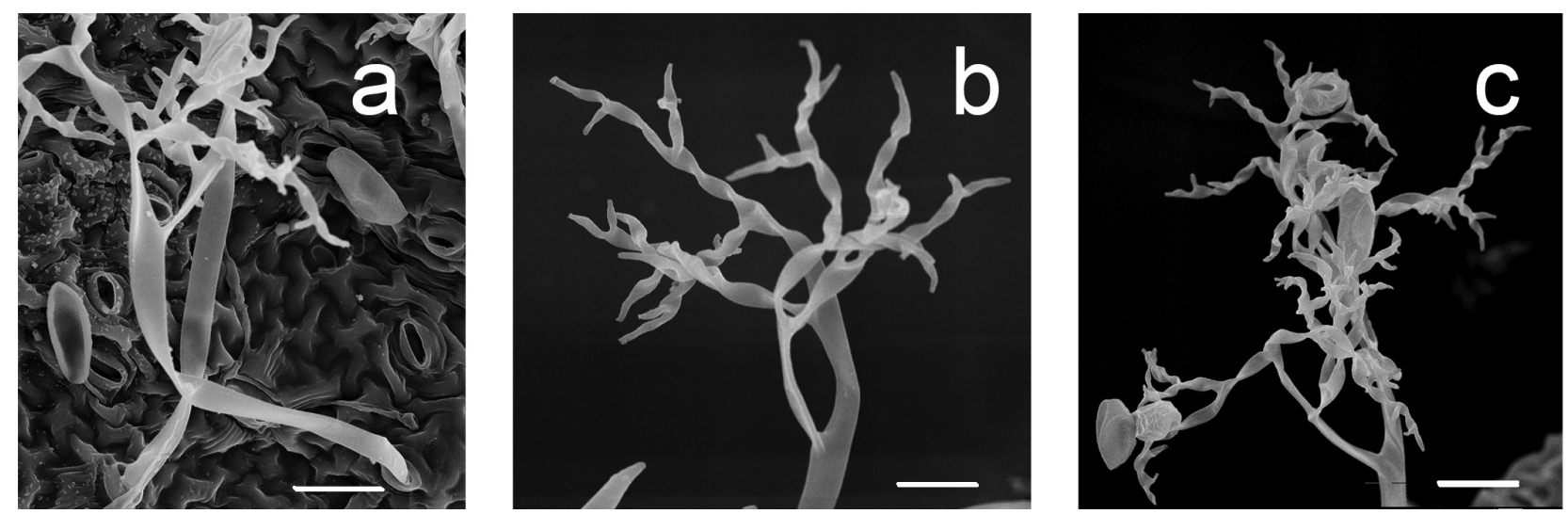

Fig. 1. Conidiosporophores of Peronospora verbenae: trunks arising through stomata $(a)$; branches and ultimate branchlets $(b, c)$; conidiospores $(a, c)$. Scale bars: $20 \mu \mathrm{m}$

to pale brown, content granular, surface from almost smooth to slightly verruculose, pedicel mostly absent, rarely scar conspicuous. Oospores not observed.

On leaves of Verbena officinalis L. - Ukraine, Odessa Region, Kiliya District, Danube Biosphere Reserve, Ermakov Island $\left(45^{\circ} 25^{\prime} \mathrm{N}, 29^{\circ} 25^{\prime} \mathrm{E}\right), 30.06 .2012$, coll. V.G. Korytnianska.

This description is almost in full agreement with those already published (Braun et al., 2009; Choi et al., 2010). Some of the known morphological characters of $P$. verbenae revealed under LM are illustrated here on the SEM pictures. These are, for example, trunk bases of conidiosporophores which can be inflated or truncate just above the point they protrude through the stomata of the host plant (Fig. 2).

However, some ultrastructural features accessible in SEM were omitted before. We have paid special attention to those characters which are usually considered in the taxonomy of Peronosporales (Thines, 2006). They are the following: morphology of the last two ramifications, particularly of the ultimate branchlets, shape of
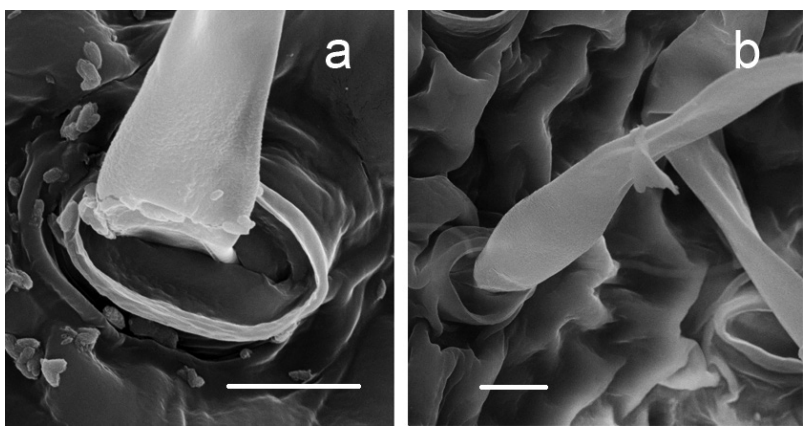

Fig. 2. Conidiosporophore trunk bases of Peronospora verbenae. Scale bars: $10 \mu \mathrm{m}$ their apical ends, anatomy of the sporangium (or conidiospore) attachment site, ornamentation of the sporangium (or conidiospore) surface, etc.

According to our observations, ultimate branchlets in $P$. verbenae are not only straight or curved (Fig. 3, $a$, $c, d$ ) but also can be spirally twisted (Fig. 3,b); tips not only more or less conical to subacute and flat (Figs. 3, $a-d$ ) but also tubular with the covering wall caving in at the apical end (Fig. 3, c). Neither distinct annulus, nor distal widening were observed in SEM. Interestingly, some ultimate branches occasionally exhibit clear broadening towards ramification (Fig. 3, $d$ ), which is typical for Paraperonospora Constant., a genus separated

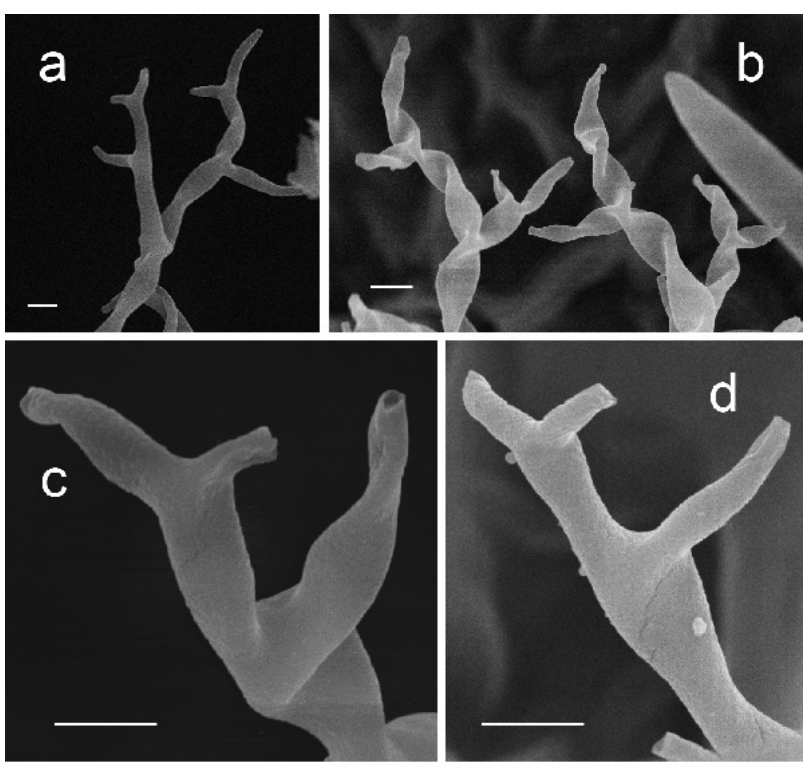

Fig. 3. Ultimate branchlets of Peronospora verbenae: straight and curved $(a)$, spirally twisted $(b)$, tubular $(c)$, broadening before ramification $(d)$. Scale bars: $5 \mu \mathrm{m}$ 
from Peronospora Corda (Constantinescu, 1989), and a few other genera of downy mildews.

The conidiospore surface in $P$. verbenae varies from slightly verruculose (Fig. 4, $a, b, d$ ) to nearly smooth (Fig. 4, c). The surface ornamentation, if present, resembles small rounded warts. It can be suggested from our material that younger conidiospores, including those still remaining within the branches (Fig. 4, $a, b$ ), are apparently more ornamented than those lying freely on the leaf underside and probably discharged earlier. The ornamentation, if present, is more or less similar all over the conidiospore surface. No clear pedicel is usually present; however, occasionally a scar can be visible (Fig. 4, c, d). Correspondingly, a papilla at the opposite end is hardly conspicuous.

Hitherto, $P$. verbenae is the only downy mildew infection recorded on Verbena and Verbenaceae in general. A previously published report of Plasmopara halstedii (Farl.) Berl. et De Toni on Verbena sp. from New Mexico, USA (Farr et al., 1989), is doubtful since downy mildews are highly host specific and the $P$. halstedii complex is confined to Asteraceae.

Verbena officinalis is a perennial herb quite common in Europe. The plant can be used in traditional medicine and as a herbal tea. In Ukraine it occurs on forest edges, waste grounds, along waysides throughout the country.
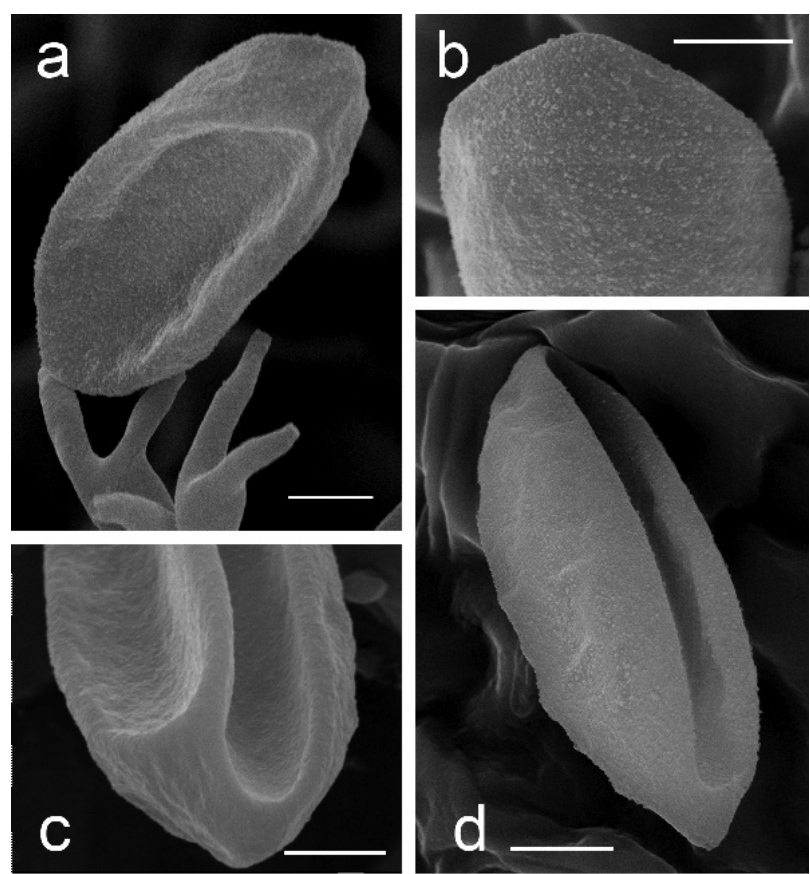

Fig. 4. Conidiospore surface of Peronospora verbenae: verruculose $(a, b, d)$ or almost smooth $(c)$. Scale bars: $5 \mu \mathrm{m}$
Nevertheless, this downy mildew is so far registered in a single locality in the south-west of the country.

Although the host plant is believed to be native to Europe, it is widely naturalized outside its native range. However, $P$. verbenae apparently remains unknown elsewhere except for Europe. According to Braun et al. (2009), it is an indigenous species which might have been overlooked before. This is entirely possible as in our collection some of the infected live leaves appear almost symptomless while on dying leaves the unclear necrotic spots become less noticeable.

Since $P$. verbenae is the only oomycete representative on the Verbenaceae, its phylogenetic origin through a host jump could be traced in downy mildews parasitizing host plants presumably from closely related families within Lamiales. Comparison with the sequences available in the GenBank database has demonstrated that the ITS sequence shares $94 \%$ similarity with Peronospora flava Gäum. (Choi et al., 2010). P. flava is known to occur on Linaria vulgaris (Plantaginaceae s.1.). However, so far it was the only sequence submitted for $P$. verbenae and used in molecular studies. More data is required for future comparison and conclusions on the origin of this species and its distribution.

The authors are grateful to Z.O. Panina, a staff member of the M.G. Kholodny Institute of Botany, for the assistance in SEM observations of the studied material.

\section{REFERENCES}

Anonymous. Verbena downy mildew // Plant Clinic News. 2009, September. - P. 1; http://www.bioimages.org.uk/ $\mathrm{html} / \mathrm{p} 7 / \mathrm{p} 78792 . \mathrm{php}$

Braun U., Jage H., Richter U., Zimmermann H. Peronospora verbenae $\mathrm{sp}$. nov. - a new downy mildew on Verbena officinalis // Schlechtendalia. - 2009. - 19. - P. 77-80.

Choi Y.J., Lebeda A., Sedlarova M., Shin H.D. First report of downy mildew caused by Peronospora verbenae on verbena in the Czech Republic // Plant Pathology. - 2010. - 59(6). P. 1166.

Constantinescu O. Peronospora complex on Compositae // Sydowia. - 1989. - 41. - P. 79-107.

Farr D.F., Rossman A. Y. Fungal Databases, Systematic Mycology and Microbiology Laboratory, ARS, SDA. Retrieved June 17, 2013, from http://nt.ars-grin.gov/fungaldatabases/

Thines $M$. Evaluation of characters available from herbarium vouchers for the phylogeny of the downy mildew genera (Chromista, Peronosporales), with focus on scanning electron microscopy // Mycotaxon. - 2006. - 97. P. $195-218$.

Recommended for publication by Submitted 19.09.2013 V.P. Heluta 
I.О. Дудка ${ }^{1}$, В.П. Гайова ${ }^{1}$, В.Г. Коритнянська ${ }^{2}$

${ }^{1}$ Інститут ботаніки імені М.Г. Холодного НАН України, м. Київ

${ }^{2}$ Національний науково-дослідний реставраційний центр

України, Одеська філія

ПЕРША В УКРАЇНI ЗНАХІДКА PERONOSPORA VERBENAE HA VERBENA OFFICINALIS

Повідомляється про першу в Україні знахідку рідкісного ооміцета Peronospora verbenae на Verbena officinalis. Цей вид, недавно описаний з Німеччини і наведений для Великої Британії та Чехії, невідомий за межами Європи. За допомогою СЕМ з'ясовані додаткові особливості ультраструктури кінцевих гілочок і поверхні конідіоспор. Представлені оригінальні ілюстрації виявлених морфологічних ознак.

Ключ чв і слова: Oomycota, Peronosporales, несправжня борошниста роса, Peronospora, Verbena.
И.А. Дудка ${ }^{1}$, В.П. Гаевая ${ }^{1}$, В.Г. Коритнянская ${ }^{2}$

${ }^{1}$ Институт ботаники имени Н.Г. Холодного НАН Украины, г. Киев

${ }^{2}$ Национальный научно-исследовательский

реставрационный центр Украины, Одесская филия

ПЕРВАЯ В УКРАИНЕ НАХОДКА PERONOSPORA VERBENAE HA VERBENA OFFICINALIS

Сообщается о первой в Украине находке редкого оомицета Peronospora verbenae на Verbena officinalis. Этот вид, недавно описанный из Германии и приведенный для Великобритании и Чехии, неизвестен за пределами Европы. При помощи СЭМ выявлены дополнительные особенности ультраструктуры конечных веточек и поверхности конидиоспор. Представлены оригинальные иллюстрации обнаруженных морфологических признаков.

Ключ е в ы е слов в: Oomycota, Peronosporales, ложная мучнистая роса, Peronospora, Verbena.

\section{НОВІ ВИДАННЯ}

Гродзинская А.А., Сырчин С.А., Кучма Н.Д., Вассер С.П. и др. Аккумулятивная активность макромищетов в условиях радионуклидного загрязнения территории Украины. - К.: Наук. думка, 2013. - 383 с.

У монографії наведено результати багаторічних досліджень мікобіоти, що зазнає впливу радіаційного стресу внаслідок Чорнобильської катастрофи. Вперше показані радіаційно індуковані реакції мікроміцетів: промислова меланізація, позитивний радіотропізм і їхня здатність до руйнування «гарячих» частинок. Узагальнено відомості щодо динаміки накопичення радіонуклідів макроміцетами в зоні відчуження та на прилеглих територіях. Для тривалого моніторингу запропоновані види-біоіндикатори (макро- і мікроміцети), адекватність яких підтверджена 20-річним терміном досліджень.

Книга буде корисною для мікологів, радіобіологів і екологів. 